\title{
Intake, nutrient digestibility and nitrogen balance in lactating dairy cows fed diets containing sunflower cake
}

\section{Consumo, digestibilidade dos nutrientes e balanço de nitrogênio em vacas leiteiras alimentadas com dietas contendo torta de girassol}

\author{
Elzânia Sales Pereira ${ }^{*}$; Patrícia Guimarães Pimentel²; \\ Greicy Mitzi Bezerra Moreno3; Ivone Yurika Mizubuti'; Edson Luis de Azambuja \\ Ribeiro4; Ana Cláudia Nascimento Campos²; Sônia Maria Pinheiro de Oliveira²; \\ Andréa Pereira Pinto ${ }^{2}$; Rebeca Magda da Silva Aquino ${ }^{5}$
}

\begin{abstract}
The objective of this study was to evaluate the effect of different levels of sunflower cake (SC) inclusion in the diets of lactating dairy cows on dry matter (DM) intake, the apparent digestibility of dietary nutrients and nitrogen balance. Eight Holstein-Zebu cows with a milk yield of $20 \pm 2 \mathrm{~kg}$ /day were allotted to a $4 \times 4$ replicated Latin square design, where were tested the effects of four levels of SC inclusion ( $(0,7,14$ and $21 \%$ of DM basis). Tifton-85 (Cynodon dactylon) hay was used as roughage in a 60:40 roughage:concentrate ratio. The SC inclusion had no effect on dry matter, crude protein, organic matter $(\mathrm{OM})$ or total carbohydrate $(\mathrm{TC})$ intake $(\mathrm{kg} /$ day). However, a quadratic effect $(\mathrm{P}<0.05)$ was detected on neutral detergent fiber and non-fibrous carbohydrate (NFC) intake (kg/day). There were no effects of SC inclusion on OM, TC and NFC digestibility, as well as, for nitrogen balance. It was observed a linear effect for the basal endogenous nitrogen (g/day). Sunflower cake can be recommended as an ingredient in the rations of lactating dairy cows.
\end{abstract}

Key words: Agro-industry residues, dairy cow, fiber

\section{Resumo}

O objetivo deste estudo foi avaliar o efeito de diferentes níveis de inclusão de torta de girassol (TG) na dieta de vacas em lactação sobre o consumo de matéria seca (MS), digestibilidade aparente dos nutrientes da dieta e balanço de nitrogênio. Oito vacas Girolanda com produção diária de leite de $20 \pm 2 \mathrm{~kg} / \mathrm{dia}$ foram distribuídas em delineamento em quadrado latino duplo $4 \mathrm{x} 4$, em que foram testados os efeitos de quatro níveis de inclusão da TG (0, 7, 14 e 21\% MS). Foi utilizado o feno de Tifton-85 (Cynodon dactylon) como volumoso em uma relação volumoso:concentrado de 60:40. A inclusão de TG não influenciou o consumo ( $\mathrm{kg} / \mathrm{dia})$ de MS, proteína bruta, matéria orgânica $(\mathrm{OM})$ e carboidratos totais $(\mathrm{CT})$. Entretanto, foi observado efeito quadrático $(\mathrm{P}<0,05)$ no consumo $(\mathrm{kg} / \mathrm{dia})$ de fibra em detergente neutro e carboidratos não-fibrosos (CNF). Não houve efeito da inclusão de TG na digestibilidade de $\mathrm{MO}, \mathrm{CT}$ e $\mathrm{CNF}$, assim como para o balanço de nitrogênio. Foi observado efeito linear para o nitrogênio endógeno basal ( $\mathrm{g} / \mathrm{dia})$. A torta de girassol pode ser recomendada como um ingrediente de rações para vacas em lactação.

Palavras-chave: Fibra, subprodutos agroindustriais, vacas leiteiras

\footnotetext{
Prof $^{a}$ Dr $^{\text {a }}$ do Dept ${ }^{\circ}$ de Zootecnia, Ceará, UFC. Bolsista de Produtividade do CNPq. Fortaleza, CE. E-mail: elzania@hotmail.com

2 Prof ${ }^{\text {as }} \operatorname{Dr}^{\text {as }}$ do Dept ${ }^{\mathrm{o}}$ de Zootecnia, UFC. Fortaleza, CE. E-mail: pgpimentel@hotmail.com; acncampos11@gmail.com; soniace@ ufc.br; deiapp@hotmail.com

3 Prof ${ }^{\mathrm{a}} \mathrm{Dr}^{\mathrm{a}}$ da Universidade Federal de Alagoas, UFAL, Arapiraca, AL. E-mail: greicymitzimoreno@yahoo.com.br

4 Profs. Drs. do Departamento de Zootecnia da Universidade Estadual de Londrina, UEL, Londrina, PR. Bolsistas de Produtividade do CNPq. Londrina, PR.E-mail: mizubuti@uel.br; elar@uel.br

5 Discente do Programa de Pós-graduação em Zootecnia, UFC, Ceará, CE. E-mail: rebeccka@gmail.com

* Author for correspondence
} 


\section{Introduction}

Lactating dairy cows require large amounts of dietary energy for maintenance, milk production and reproduction (RABELO et al., 2003). Feeding diets containing more than $50 \%$ of ration dry matter (DM) as forage to highly productive dairy cows has been shown to support similar levels of milk production (CHERNEY; CHERNEY; CHASE, 2004). High quality forages have high digestibility and can be consumed in greater quantities than low quality forages that have a high NDF and low digestibility (LLAMAS-LAMAS; COMBS, 1991). The main factors that might affect the partitioning of energy in lactating cows are energy intake, health status, environmental conditions and individual variability among cows with respect to the efficiency of energy utilization for maintenance and production (BROSH, 2007).

Appropriate feeding management and the use of intensive systems of exploitation may be favorable strategies for improving dairy production, especially during the dry season, which makes the use of nutritional and low cost foods essential (PEREIRA et al., 2009). Sunflower can consist in an alternative for energy and protein supplementation for animals in regions where soybean and maize could not produce successfully (NGONGONI et al., 2007), like in northeastern Brazil.

Agro-industry residues may be valuable sources of protein, fiber and energy. Sunflowers are grown for oil extraction from whole or dehulled seeds, generating large amounts of by-products. Different by-products are obtained according to extraction method: sunflower cake from mechanical oil extraction and sunflower meal from chemical extraction with solvents. The nutritional composition of sunflower by-products is variable and directly related to the oil extraction process and the amount of bark remaining (ENSMINGER; OLDFIELD; HEINEMANN, 1990).

The use of sunflower seed as a source of biofuel provides interesting opportunities for farmers, both in terms of oil production and interesting byproducts. The cake resulting from the grain pressing to obtain sunflower oil is an ingredient nutritionally rich for animal feed, containing high levels of protein, lipid and fiber (OLIVEIRA; CÁCERES, 2005). Considering other advantages of using byproducts and co-products from the biofuels industry, there is the possibility of obtaining gain from the carbon credit market, due reduction of emission of methane gas when using rations containing oil (ABDALLA et al., 2008). According to studies conducted in Australia and Canada, for each 1\% increase of fat in the diet of ruminant can be reduced up to $6 \%$ the amount of methane produce per $\mathrm{kg}$ of dry matter consumed (LIMA, 2011).

Information about the use of sunflower cake in feeds is scarce (MATTII; PRIORI; TROMBETTA, 2009). Although research performed in several countries has provided some information about sunflower cake, an understanding of its nutritional properties is required in order to use these products in animal feeding. Therefore, the objective of this study was to evaluate intake, apparent digestibility and nitrogen compound balance in lactating cows fed diets containing different levels of sunflower cake.

\section{Materials and Methods}

\section{Animals, experimental design and diets}

The experiment was carried out in Quixeramobim, Ceara, Brazil, which has a semi-arid climate. Eight lactating Holstein-Zebu cows were used, with an average weight of $515 \pm 21 \mathrm{~kg}$, milk production of $20 \pm 2 \mathrm{~kg} / \mathrm{d}, 7$ to 10 weeks postpartum and a parity of $3.0 \pm 1$. The animals were randomly distributed in a $4 \times 4$ replicated Latin square design. The animals were weighed at the beginning and at the end of each experimental period. Animal care and handling procedures were followed according to the University's animal care committee.

The animals were kept in a feedlot system 
in individual covered pens, supplied with an individual feeder and drinker. Animals were fed a diet containing Tifton-85 (Cynodon dactylon) hay and concentrate (60 and 40\%, respectively, on DM basis). The Tifton-85 hay presented low quality, with an average of CP and NDF of $96.88 \mathrm{~g} / \mathrm{kg}$ of $\mathrm{DM}$ and $834.47 \mathrm{~g} / \mathrm{kg}$ of DM, respectively (Table 1).
The treatments consisted of four levels of sunflower cake inclusion in the concentrate ration $(0,7,14$ and $21 \%$ of DM; Table 2). The diets were formulated to provide $13.0 \%$ of $\mathrm{CP}$ and to meet the nutritional requirements of a cow, with $550 \mathrm{~kg}$, producing 20 $\mathrm{kg}$ of milk containing $3.5 \%$ fat (NRC, 2001).

Table 1. Chemical composition of Tifton-85 hay (TH), corn meal (CM), soybean meal (SBM), wheat bran (WB) and sunflower cake (SC), in $\mathrm{g} / \mathrm{kg} \mathrm{DM}$.

\begin{tabular}{lccccc}
\hline \multirow{2}{*}{ Chemical analysis } & \multicolumn{5}{c}{ Ingredients } \\
\cline { 2 - 6 } & TH & CM & SBM & WB & SC \\
\hline Dry matter & 843.10 & 816.60 & 836.41 & 799.01 & 836.55 \\
Crude protein & 96.88 & 100.43 & 502.83 & 166.39 & 223.29 \\
Ether extract & 16.21 & 46.72 & 25.34 & 56.48 & 116.28 \\
Neutral detergent fiber & 834.47 & 217.29 & 167.70 & 352.55 & 537.71 \\
Acid detergent fiber & 403.01 & 88.45 & 112.07 & 117.78 & 176.89 \\
Total carbohydrates & 795.79 & 826.77 & 396.54 & 538.27 & 654.64 \\
Non-fibrous carbohydrates & 33.93 & 646.52 & 275.98 & 255.39 & 183.47 \\
\hline
\end{tabular}

Source: Elaboration of the authors.

Table 2. Proportion (\% DM) of ingredients ( $\mathrm{g} / \mathrm{kg} \mathrm{DM})$ of the diets.

\begin{tabular}{|c|c|c|c|c|}
\hline \multirow{3}{*}{ Ingredients } & \multicolumn{4}{|c|}{ Inclusion levels of sunflower cake (\%) } \\
\hline & $\mathbf{0}$ & 7 & 14 & 21 \\
\hline & \multicolumn{4}{|c|}{ Proportion of the ingredients in the diets (\% DM) } \\
\hline Tifton-85 hay & 60.00 & 60.00 & 60.00 & 60.00 \\
\hline Corn meal & 23.08 & 22.39 & 22.73 & 21.63 \\
\hline Soybean meal & 9.26 & 7.26 & 5.13 & 3.33 \\
\hline Wheat meal & 6.68 & 6.62 & 5.80 & 5.86 \\
\hline Sunflower cake & 0.00 & 2.80 & 5.60 & 8.40 \\
\hline Limestone & 0.52 & 0.54 & 0.54 & 0.54 \\
\hline Dicalcium phosphate & 0.29 & 0.22 & 0.13 & 0.07 \\
\hline Mineral mixture $^{1}$ & 0.16 & 0.16 & 0.16 & 0.16 \\
\hline Chemical analysis & \multicolumn{4}{|c|}{ Composition of diets (g/kg DM) } \\
\hline Dry matter & 835.61 & 835.22 & 834.04 & 838.29 \\
\hline Crude protein & 138.88 & 134.28 & 128.79 & 124.98 \\
\hline Ether extract & 27.14 & 29.79 & 31.15 & 35.41 \\
\hline Neutral detergent fiber & 781.61 & 784.82 & 802.77 & 794.07 \\
\hline Acid detergent fiber & 279.30 & 281.86 & 290.83 & 290.59 \\
\hline Total carbohydrates & 769.94 & 770.23 & 765.71 & 765.48 \\
\hline Non-fibrous carbohydrates & 241.67 & 211.55 & 191.71 & 198.87 \\
\hline $\operatorname{TDN}(\% \text { of DM })^{2}$ & 67.30 & 69.48 & 65.80 & 77.61 \\
\hline
\end{tabular}




\section{Experimental procedures and sample collection}

Cows were fed ad libitum twice a day (8:00 and 16:00 h) and milked twice daily at 6:00 and 16:00 h. Feed refusals were measured before morning feeding and the amount of feed offered was adjusted to allow $10 \%$ refusal. The animals had free access to water throughout the trial.

The experimental period lasted 64 days and each period consisted of 10 days of adaptation (FERREIRA et al., 2009) and 6 days of sample collection. Samples of experimental diets and refusal were weighed daily and stored $\left(-20^{\circ} \mathrm{C}\right)$ for subsequent chemical analysis. Feces were collected from the rectum in the morning and afternoon of the collection period, in order to estimate the digestibility of dietary constituents. A sub-sample was taken, weighed and dried in a forced air oven at $55^{\circ} \mathrm{C}$ for $72 \mathrm{~h}$, and then ground through a $1-\mathrm{mm}$ screen (Wiley mill; Arthur H. Thomas, Philadelphia, PA). At the end of each experimental period, a composite sample was made for each animal, based on the pre-dried weight of each sampling day.

Indigestible NDF was used as the internal marker to calculate fecal excretion and the apparent digestibility of nutrients. The indigestible content of the composited total mixed ratio (TMR), orts and fecal samples was determined using in situ incubation (LYKOS; VARGA, 1995).

On the $16^{\text {th }}$ day of each period, two urine samples (morning and afternoon) were collected from each animal by spontaneous urination approximately 4 hours after feed supply. The samples were stored at $-20^{\circ} \mathrm{C}$ prior to laboratory analysis. At the end of the experiment, samples were thawed and homogenized for preparation of a composite sample per cow per period for quantification of creatinine and urinary nitrogen.

\section{Chemical analyses}

Total dry matter was analyzed by drying the sample at $105^{\circ} \mathrm{C}$ to a constant weight (method
930.15; AOAC, 1990). Total nitrogen was measured using the Kjeldahl method (method 955.04; AOAC, 1990). Crude protein (CP) was calculated by multiplying $\% \mathrm{~N}$ by a factor of 6.25 (method 984.13; AOAC, 1990). Acid detergent fiber (ADF) was determined using acetyl-trimethyl ammonium bromide detergent in $0.5 \mathrm{M}$ sulfuric acid (GOERING; VAN SOEST, 1970). Neutral detergent fiber (NDF) was determined using sodium sulfite and amylase (VAN SOEST; ROBERTSON; LEWIS, 1991).

Carbohydrates (TC) were determined using the following equation: $\mathrm{TC}=100-(\% \mathrm{CP}+\% \mathrm{EE}$ $+\% \mathrm{MM})$ (SNIFFEN et al., 1992). Non-fibrous carbohydrates $(\mathrm{A}+\mathrm{B} 1)$ were determined according to the following equation: $\mathrm{NFC}=100-(\% \mathrm{CP}+$ $\% \mathrm{EE}+\% \mathrm{NDF} a p+\% \mathrm{MM})$, in which NDFap is equivalent to the cell wall corrected for ash and protein. Total digestible nutrients (TDN) were calculated according to Sniffen et al. (1992), using the following equation: $\mathrm{TDN}=\mathrm{DCP}+(\mathrm{DEE} \times 2.25)$ + DTC, in which, DCP = apparent digestible crude protein, $\mathrm{DEE}=$ apparent digestible ether extract and $\mathrm{TDC}=$ apparent digestible total carbohydrate.

Creatinine was determined with commercial kits $\left(\right.$ Labtest $^{\circledR}$, Lagoa Santa, Minas Gerais, Brazilian Industry), following the end-point method, using picrate and acidifier. Urine volume (UV) was estimated according to the equation: UV $(\mathrm{L} / \mathrm{d})=(29 \times$ live weight, $\mathrm{kg}) /($ creatinine, $\mathrm{mg} / \mathrm{L})$ (VALADARES FILHO; VALADARES, 2001), in which, 29 = average daily creatine excretion in $\mathrm{mg} /$ $\mathrm{kg} \mathrm{BW}$, obtained for dairy cows.

Nitrogen balance (NB) was calculated from the amounts of $\mathrm{N}(\mathrm{g} / \mathrm{d})$ consumed and excreted in the feces, in the urine and in the milk, as follows: NB $(\mathrm{g} / \mathrm{d})=$ Nconsumed - Nfeces - Nurine - Nmilk. Nitrogen content in the milk was obtained by dividing the milk $\mathrm{CP}$ by conversion factor 6.38 (MCDONALD, 1993). Basal endogenous nitrogen (BEN) was calculated using the following equation: $\operatorname{BEN}(\mathrm{g} / \mathrm{d})=(0.35+0.018) \times \mathrm{BW}^{0.75}(\mathrm{AFRC}, 1993)$. 
The value of $\mathrm{N}$ retained (NR) was expressed as: NR $(\mathrm{g} / \mathrm{d})=\mathrm{NB}-\mathrm{BEN}$.

\section{Statistical analysis}

Data for intake, the apparent digestibility of dietary constituents and nitrogen balance were subjected to ANOVA for a 4 x 4 replicated Latin square design. Terms in the model included square, period (square), cow (square), treatment, and the interaction of treatment and square. An orthogonal partition of the sum of squares of treatments into linear and quadratic degree effects was obtained following the analysis of variance. All statistical analyses were performed using the PROC GLM procedure in SAS 9.0 (SAS, 2005) and a probability level of 0.05 , as the follow statist model.

$$
\mathrm{Y}_{\mathrm{ijkl}}=\mu+\mathrm{S}_{\mathrm{i}}+\mathrm{T}_{1}+\mathrm{P}_{\mathrm{j}(\mathrm{i})}+\mathrm{C}_{\mathrm{k}(\mathrm{i})}+\mathrm{ST}_{\mathrm{il}}+\varepsilon_{\mathrm{ijk} \mathrm{l}} \text {, where: }
$$

$\mathrm{Y}_{\mathrm{ijkl}}$ is the dependent variable;

$\mu$ is the overall mean;

$\mathrm{S}_{\mathrm{i}}$ is the effect of square $\mathrm{i}$;

$\mathrm{T}_{1}$ is the effect of treatment 1 ;

$P_{j(i)}$ is the effect of period $j$ (within square $i$ );

$\mathrm{C}_{\mathrm{k}(\mathrm{i})}$ is the effect of cow $\mathrm{k}$ (within square $\mathrm{i}$ );

$\mathrm{ST}_{\mathrm{il}}$ is the interaction between square $\mathrm{i}$ and treatment $1 ;$

$\varepsilon_{\mathrm{ijkl}}$ is the residual error.

\section{Results and Discussion}

The sunflower cake is an alternative source of protein and energy, but can present extreme variation in lipid content (60.0 to $300.0 \mathrm{~g} / \mathrm{kg}$ ) and the high content of polyunsaturated lipids can improve the milk quality (OLIVEIRA; VIEIRA, 2004). The discovery using animal models and tissue culture that conjugated linoleic acid (CLA), which is found in dairy products (LIN et al., 1995), possesses potential beneficial effects to human health is a positive health image of milk fat (PARODI, 1997).

There was no effect of sunflower cake inclusion on DM, OM, CP and TC intake expressed as $\mathrm{kg} / \mathrm{d}$, with average values of 14.06, 10.31, 1.8 and 10.36 $\mathrm{kg} / \mathrm{d}$, respectively (Table 3 ). The DM intake also did not present difference when expressed in \%BW (2.74\%) or $\mathrm{g} / \mathrm{kg}^{0.75}\left(130.89 \mathrm{~g} / \mathrm{kg}^{0.75}\right)$ (Table 3). According to NRC (2001) for cows with average milk production of $20 \mathrm{~kg} /$ day weighing $500 \mathrm{~kg}$, the DM intake is $16.0 \mathrm{~kg} /$ day, value higher than obtained in this study. These differences may be related to the diet, environment and genotype, because crossbred Holstein-Zebu cows are more adapted to tropical conditions, present smaller frame size in maturity and therefore have lower dry matter intake, as was observed in this work. According to Mertens (1987), when the energy density of the diet is high (low NDF), in relation to requirements of the animal, intake may be limited by energy demand, not occurring rumen fill. For diets of low energy density (high content of NDF), the intake can be limited by the filling of the rumen reticulum.

Santos et al. (2009) studying the effect of inclusion of sunflower cake in the diet of lactating Holstein cows did not observed differences in intake with a mean value of $14.8 \mathrm{~kg} \mathrm{DM} /$ day and $3.0 \%$ BW, similar to the obtained in this study.

A quadratic effect of SC levels in the diet on the NDF $(\mathrm{P}<0.05)$ and NFC $(\mathrm{P}<0.05)$ intakes $(\mathrm{kg} / \mathrm{d})$ was detected, with critical points (maximum response) at the SC levels of 14.01 and $13.02 \% \mathrm{DM}$, respectively. A similar pattern was also observed for NDF $(\mathrm{P}<0.05)$ intake, when expressed in $\% \mathrm{BW}$ and $\mathrm{g} / \mathrm{kg}^{0.75}$, with critical points (maximum response) at SC levels of 11.73 and $12.64 \%$ DM, respectively. On the other hand, ADF intake $(\mathrm{kg} / \mathrm{d})$ increased linearly $(\mathrm{P}<0.05)$ as the $\mathrm{SC}$ levels in the diet increased (Table 3).

The inclusion of SC at the levels of $0,7,14$ and $21 \%$ provided intake of NDF of $16.01,16.52$, 
18.35 and $16.97 \mathrm{~g} / \mathrm{kg} \mathrm{BW}$, respectively. This can be attributed to the high levels of NDF in the experimental diets (781.61, 784.82, 802.77 and $794.07 \mathrm{~g} / \mathrm{kg}$ DM, respectively) due the high levels of NDF in the Tifton-85 hay used (Table 1). This high level of indigestible NDF promoted the filling effect. The apparent digestibility of DM was higher than $69 \%$ for all experimental diets (Table 4), which may lead to incorrect interpretation of the physiological limitation of consumption. However, the model NDF-energy intake, formulated by Mertens (1994), provides that the intake is limited by the filling when the daily intake of NDF is greater than 11 to $13 \mathrm{~g} / \mathrm{kg} \mathrm{BW}$. Thus, for the present experiment can be inferred that the intake was regulated by physical mechanisms, as the NDF intake ranged from 16.3 to $18.0 \mathrm{~g} / \mathrm{kg} \mathrm{BW}$ (Table 3).

Table 3. Least squares means and mean square error (MSE) for average daily intake of dry matter (DM), organic matter (OM), crude protein (CP), ether extract (EE), neutral detergent fiber (NDF), acid detergent fiber (ADF), total carbohydrate (TC), non-fibrous carbohydrate (NFC) and total digestible nutrients (TDN) according to sunflower cake levels in the diet

\begin{tabular}{|c|c|c|c|c|c|c|}
\hline \multirow{2}{*}{ Variables } & \multicolumn{4}{|c|}{ Inclusion levels of sunflower cake (\%) } & \multirow{2}{*}{$\mathbf{P}>\mathbf{F}$} & \multirow{2}{*}{ MSE } \\
\hline & $\mathbf{0}$ & 7 & 14 & 21 & & \\
\hline \multicolumn{7}{|c|}{$(\mathrm{kg} / \mathrm{d})$} \\
\hline $\mathrm{DM}^{\mathrm{a}}$ & 13.62 & 13.87 & 14.74 & 14.01 & ns & 0.66 \\
\hline $\mathrm{OM}^{\mathrm{b}}$ & 10.25 & 10.09 & 10.65 & 10.24 & $\mathrm{~ns}$ & 0.43 \\
\hline $\mathrm{CP}^{\mathrm{c}}$ & 1.85 & 1.82 & 1.83 & 1.70 & ns & 0.01 \\
\hline $\mathrm{EE}^{\mathrm{d}}$ & 0.39 & 0.59 & 0.84 & 1.09 & 0.001 & 0.004 \\
\hline $\mathrm{NDF}^{\mathrm{e}}$ & 8.28 & 8.51 & 9.45 & 8.74 & 0.030 & 0.30 \\
\hline $\mathrm{ADF}^{\mathrm{f}}$ & 3.71 & 3.80 & 4.14 & 3.94 & 0.013 & 0.05 \\
\hline $\mathrm{TC}^{\mathrm{g}}$ & 10.41 & 10.51 & 9.96 & 10.57 & ns & 0.34 \\
\hline $\mathrm{NFC}^{\mathrm{h}}$ & 1.80 & 2.28 & 2.20 & 2.15 & 0.001 & 0.03 \\
\hline $\mathrm{TDN}^{\mathrm{i}}$ & 9.18 & 9.66 & 9.70 & 10.88 & 0.001 & 0.49 \\
\hline \multicolumn{7}{|c|}{$(\% \mathrm{BW})$} \\
\hline $\mathrm{DM}^{\mathrm{j}}$ & 2.69 & 2.80 & 2.80 & 2.69 & ns & 0.03 \\
\hline $\mathrm{NDF}^{\mathrm{k}}$ & 1.63 & 1.73 & 1.80 & 1.69 & 0.020 & 0.01 \\
\hline $\mathrm{TC}^{\mathrm{l}}$ & 2.05 & 2.09 & 1.87 & 2.01 & ns & 0.02 \\
\hline $\mathrm{NFC}^{\mathrm{m}}$ & 2.31 & 2.31 & 2.03 & 2.22 & 0.01 & 0.02 \\
\hline \multicolumn{7}{|c|}{$\left(\mathrm{g} / \mathrm{kg}^{0.75}\right)$} \\
\hline $\mathrm{DM}^{\mathrm{n}}$ & 127.48 & 132.70 & 134.33 & 129.07 & ns & 63.12 \\
\hline $\mathrm{NDF}^{\circ}$ & 77.40 & 82.05 & 86.45 & 81.06 & 0.020 & 27.56 \\
\hline $\mathrm{TDN}^{\mathrm{p}}$ & 85.90 & 90.99 & 87.59 & 98.81 & 0.001 & 46.54 \\
\hline $\begin{array}{l}{ }^{\mathrm{a}} \tilde{Y}=14.0609 \\
{ }^{\mathrm{d}} \tilde{Y}=10.3050 \\
{ }^{\circ} \tilde{Y}=1.5900 \\
{ }^{\mathrm{d}} \hat{Y}=0.3754+ \\
{ }^{\mathrm{e}} \hat{Y}=8.1584+ \\
{ }^{\mathrm{f}} \hat{Y}=3.7408+ \\
{ }^{\mathrm{g}} \tilde{Y}=10.3625 \\
{ }^{\mathrm{h}} \hat{Y}=1.8286+ \\
{ }^{\mathrm{i}} \hat{Y}=9.0841+ \\
\text { Source: Elabc }\end{array}$ & $\begin{array}{l}X X\left(R^{2}=0\right. \\
X-0.004 \\
X\left(R^{2}=0\right. \\
X-0.002 \\
X\left(R^{2}=0\right. \\
\text { of the autl }\end{array}$ & $\left(\mathrm{R}^{2}=0.64\right)$ & \multicolumn{4}{|c|}{$\begin{array}{l}{ }^{j} \tilde{Y}=2.7456 \\
{ }^{k} \hat{Y}=1.6250+0.0258 X-0.0011 X 2\left(R^{2}=0.72\right) \\
{ }^{1} \tilde{Y}=2.0050 \\
{ }^{\mathrm{m}} \hat{Y}=2.3018-0.0081 X\left(R^{2}=0.84\right) \\
{ }^{n} \tilde{Y}=130.8925 \\
{ }^{\circ} \hat{Y}=76.9200+1.2970 X-0.0513 X^{2}\left(R^{2}=0.61\right) \\
{ }^{\mathrm{P}} \hat{Y}=85.5276+0.5045 X\left(R^{2}=0.63\right)\end{array}$} \\
\hline
\end{tabular}


The digestibility coefficient of DM and NDF showeda linear response $(\mathrm{P}<0.05)$ to increasinglevels of SC inclusion, therefore, the ether extract content were not high enough to alter the fiber digestion. The $\mathrm{CP}$ and EE showed a quadratic response $(\mathrm{P}<0.05)$, with the maximum effect at 12.24 and over $21 \%$ of $\mathrm{SC}$, respectively. High levels of ADF in the diet can affect the digestibility of nutrients, given that the lignin fraction (indigestible) represents the largest proportion of ADF (EASTRIDGE, 1997). Despite the high ADF content of sunflower cake, there was no reduction in the digestibility of nutrients, which can be considered a satisfactory result for the studied levels (Table 1 and 4).

Table 4. Least square means and mean square error (MSE) for apparent digestibility coefficients (\%) of dry matter $(\mathrm{DM})$, organic matter $(\mathrm{OM})$, crude protein $(\mathrm{CP})$, ether extract (EE), neutral detergent fiber (NDF) and total carbohydrate (TC) and non-fibrous carbohydrate (NFC) according to sunflower cake levels in the diet.

\begin{tabular}{lcccccc}
\hline \multirow{2}{*}{ Variables } & \multicolumn{9}{c}{ Inclusion levels of sunflower cake (\%) } & \multirow{2}{*}{ P>F } & \multirow{2}{*}{ MSE } \\
\cline { 2 - 5 } & $\mathbf{0}$ & $\mathbf{7}$ & $\mathbf{1 4}$ & $\mathbf{2 1}$ & & 3.35 \\
$\mathrm{DM}^{\mathrm{a}}$ & 69.96 & 71.81 & 72.07 & 72.43 & 0.020 & 6.20 \\
$\mathrm{OM}^{\mathrm{b}}$ & 65.20 & 65.93 & 66.16 & 66.76 & $\mathrm{~ns}$ & 1.86 \\
$\mathrm{CP}^{\mathrm{c}}$ & 75.06 & 75.47 & 77.34 & 75.42 & 0.030 & 2.08 \\
$\mathrm{EE}^{\mathrm{d}}$ & 69.17 & 80.12 & 85.65 & 89.50 & 0.001 & 4.96 \\
$\mathrm{NDF}^{\mathrm{e}}$ & 59.85 & 62.39 & 63.21 & 64.13 & 0.002 & 2.64 \\
$\mathrm{TC}^{\mathrm{f}}$ & 70.80 & 71.99 & 68.87 & 72.49 & $\mathrm{~ns}$ & 2.68 \\
$\mathrm{NFC}^{\mathrm{g}}$ & 87.29 & 88.97 & 87.08 & 88.73 & $\mathrm{~ns}$ & \\
\hline
\end{tabular}

${ }^{\mathrm{a}} \hat{\mathrm{Y}}=70.4172+0.1099 \mathrm{X}\left(\mathrm{R}^{2}=0.81\right)$

${ }^{\mathrm{b}} \tilde{\mathrm{Y}}=66.01$

${ }^{c} \hat{Y}=74.7980+0.2914 X-0.0119 X^{2}\left(R^{2}=0.86\right)$

${ }^{\mathrm{d}} \hat{\mathrm{Y}}=69.3544+1.7117 \mathrm{X}-0.0363 \mathrm{X}^{2}\left(\mathrm{R}^{2}=0.99\right)$

Source: Elaboration of the authors.

The amount of $\mathrm{N}$ excreted in milk was associated quadratically $(\mathrm{P}<0.05)$ with the SC levels in the diet, with the maximum at $7.17 \%$ SC (Table 5). Basal endogenous nitrogen (BEN) (g/d) showed a linear response to SC. According to Riis (1983), the protein deposition rate increases up to a certain level as the supply of energy, protein and other nutrients increases. The highest intakes of TDN were recorded in diets with high levels of SC. This suggests the availability of nutrients for the deposition and renewal of tissue proteins, which was supported by the analysis of $\mathrm{N}$ retention by animals, indicating net $\mathrm{N}$ available for gain. 
Table 5. Least square means and mean square error (MSE) for milk production (MP), milk urea nitrogen (MUN), nitrogen consumed (NC), nitrogen excreted in feces (NF), in the urine (NU) and in the milk (NM), nitrogen balance (NB), basal endogenous nitrogen (BEN) and nitrogen retention (NR) according to sunflower cake levels in the diet

\begin{tabular}{lcccccc}
\hline \multirow{2}{*}{ Variables } & \multicolumn{3}{c}{ Inclusion levels of sunflower cake (\%) } & \multirow{2}{*}{ P>F } & \multirow{2}{*}{ MSE } \\
\cline { 2 - 5 } & $\mathbf{0}$ & $\mathbf{7}$ & $\mathbf{1 4}$ & $\mathbf{2 1}$ & & \\
\hline MP $(\mathrm{kg} / \mathrm{day})^{\mathrm{a}}$ & 18.88 & 19.92 & 20.56 & 19.29 & 0.001 & 0.50 \\
$\mathrm{MUN}(\mathrm{mg} / \mathrm{dL})^{\mathrm{b}}$ & 13.04 & 13.15 & 12.40 & 11.65 & 0.001 & 0.49 \\
$\mathrm{NC}(\mathrm{g} / \mathrm{d})^{\mathrm{c}}$ & 238.78 & 241.53 & 250.06 & 234.53 & $\mathrm{~ns}$ & 163.42 \\
$\mathrm{NF}(\mathrm{g} / \mathrm{d})^{\mathrm{d}}$ & 68.17 & 64.82 & 65.76 & 65.22 & $\mathrm{~ns}$ & 33.85 \\
$\mathrm{NU}(\mathrm{g} / \mathrm{d})^{\mathrm{e}}$ & 1.55 & 1.40 & 1.16 & 1.48 & $\mathrm{~ns}$ & 0.26 \\
$\mathrm{NM}(\mathrm{g} / \mathrm{d})^{\mathrm{f}}$ & 9.59 & 9.64 & 9.75 & 8.66 & 0.002 & 0.19 \\
$\mathrm{NB}(\mathrm{g} / \mathrm{d})^{\mathrm{g}}$ & 159.47 & 165.67 & 173.40 & 159.17 & $\mathrm{~ns}$ & 179.16 \\
$\mathrm{BEN}(\mathrm{g} / \mathrm{d})^{\mathrm{h}}$ & 39.42 & 39.23 & 40.78 & 40.51 & 0.001 & 0.08 \\
$\mathrm{NR}(\mathrm{g} / \mathrm{d})^{\mathrm{i}}$ & 120.05 & 126.44 & 132.62 & 118.66 & $\mathrm{~ns}$ & 181.52 \\
\hline
\end{tabular}

${ }^{a} \hat{Y}=19.6311+0.0002 X\left(R^{2}=0.82\right)$ by Pereira et al. $(2011)$

${ }^{\mathrm{b}} \hat{\mathrm{Y}}=13.2963-0.0702 \mathrm{X}\left(\mathrm{R}^{2}=0.84\right)$ by Pereira et al. $(2011)$

${ }^{\mathrm{c}} \tilde{\mathrm{Y}}=241.2258$

$\mathrm{d} \tilde{\mathrm{Y}}=65.9906$

${ }^{\mathrm{e}} \tilde{Y}=1.3986$

$$
\begin{aligned}
& { }^{\mathrm{f}} \hat{Y}=9.5264+0.0846 X-0.0059 X^{2}\left(R^{2}=0.90\right) \\
& { }^{g} \tilde{Y}=164.4260 \\
& { }^{h} \hat{Y}=39.2609+0.0690 X\left(R^{2}=0.65\right) \\
& { }^{\mathrm{i}} \tilde{Y}=124.4403
\end{aligned}
$$

Source: Elaboration of the authors.

\section{Conclusions}

Sunflower cake can be recommended as an ingredient in the rations of lactating dairy cows.

\section{Acknowledgments}

The authors wish to thank the Conselho Nacional de Pesquisa e Desenvolvimento Científico e Tecnológico (CNPq) for financial support.

\section{References}

ABDAlla, A. L.; SILVA FILHO, J. C.; GODOI, A. R.; CARMO, C. A.; EDUARDO, J. L. P. Utilização de subprodutos da indústria de biodiesel na alimentação de ruminantes. Revista Brasileira de Zootecnia, Viçosa, MG, v. 37, p. 260-258, 2008. Suplemento especial.

AGRICULTURALAND FOOD RESEARCH COUNCIL - AFRC. Energy and protein requirements of ruminants. CAB International, Wallingford, UK, 1993. 159 p.

ASSOCIATION OF OFFICIAL ANALYTICAL CHEMISTRY - AOAC. Official methods of analysis. 15. ed. Arlington: AOAC International, 1990. 1117 p.
BROSH, A. Heart rate measurements as an index of energy expenditure and energy balance in ruminants: a review. Journal of Animal Science, Madison, v. 85, n. 5, p. 1213-1227, 2007.

CHERNEY, D. J. R.; CHERNEY, J. H.; CHASE, L. E. Lactation performance of Holstein cows fed fescue, orchard grass, or alfalfa silage. Journal of Dairy Science, Madison, v. 87, n. 7, p. 2268-2276, 2004.

EASTRIDGE, M. L. Fibra para vacas leiteiras. In: SIMPÓSIO SOBRE PRODUÇÃO ANIMAL, 9., 1997, Piracicaba. Anais... Piracicaba: FEALQ, 1997. p. 33-50.

ENSMINGER, M. E.; OLDFIELD, J. E.; HEINEMANN, W. W. Feeds and nutrition. 2. ed. Clovis, California: Ensminger Publishing Company. 1990. 1544 p.

FERREIRA, M.A.; VALADARES FILHO, S. C.; COSTA E SILVA, L. F.; NASCIMENTO, F. B.; DETMANN, E.; VALADARES, R. F. D. Avaliação de indicadores em estudos com ruminantes: estimativa de consumos de concentrado e de silagem de milho por vacas em lactação. Revista Brasileira de Zootecnia, Viçosa, MG, v. 38, n. 8, p. 1574-1580, 2009.

GOERING, H. K.; VAN SOEST, P. J. Forage fiber analysis (apparatus, reagents, procedures and some applications). Washington, DC, USDA, 1970. (Agricultural Handbook, 379). 
LIMA, H. L. Parâmetros nutricionais em novilhos suplementados com torta de girassol em pastejo de Brachiaria brizantha cv. marandu. 2011. Dissertação (Mestrado em Zootecnia) - Universidade Federal da Grande Dourados, Dourados.

LIN, H.; BOYLSTON, T. D.; CHANG, M. J.; LUEDEKE, L. O.; SHULTZ, T. D. Survey of the conjugated linoleic content of dairy products. Journal of Dairy Science, Madison, v. 78, n. 11, p. 2358-2365, 1995.

LLAMAS-LAMAS, G.; COMBS, D. K. Effect of forage to concentrate ratio and intake level on utilization of early vegetative alfalfa silage by dairy cows. Journal of Dairy Science, Madison, v. 74, n. 2, p. 526-536, 1991.

LYKOS, T.; VARGA, G. Effects of processing method on degradation characteristics of protein and carbohydrate sources in situ. Journal of Dairy Science, Madison, v. 78, n. 8, p. 1789-1801, 1995.

MATTII, S.; PRIORI, S.; TROMBETTA, M. F. Influence of sunflower cake supplementation on Marchigiana carcass and meat quality. Italian Journal of Animal Science, Pavia, v. 8, n. 2, p. 513-515, 2009.

MCDONALD, P. Evaluation of foods (D) protein. In: MCDONALD, P.; EDWARDS, R.; GREENHALGH, J. F. D. (Ed.). Nutrition animal. 4. ed. Zaragoza: Acríbia, 1993. p. 29-57.

MERTENS, D. R. Predicting intake and digestibility using mathematical models of ruminal function. Journal of Animal Science, Madison, v. 64, n. 5, p. 1548-1558, 1987.

Regulation of forage intake. In: FOHEY JUNIOR, G. C. (Ed.). Forage quality, evaluation, and utilization. Madison: ASA-CSSA-SSSA, 1994. p. 450532.

NATIONAL RESEARCH COUNCIL - NRC. Nutrient requirements of dairy cattle. Washington: National Academy Press, 2001. 368 p.

NGONGONI, N. T.; MAPIYE, C.; MWALE, M.; MUPETA, B. Effect of supplementing a high-protein ram press sunflower cake concentrate on smallholder milk production in Zimbabwe. Tropical Animal Health and Production, Heidelberg, v. 39, n. 4, p. 297-307, 2007.

OLIVEIRA, M. D. S.; CÁCERES, D. R. Girassol na alimentação de bovinos. Jaboticabal: Funep, 2005. 20 p.

OLIVEIRA, M. F.; VIEIRA, O. V. Extração de óleo girassol utilizando-se miniprensa. Londrina: Embrapa Soja, 2004. 30 p. (Documento, 237).
PARODI, P. W. Cow's milk fat components as potential anticarcinogenic agents. The Journal of Nutrition, Bethesda, v. 127, n. 6, p. 1055-1060, 1997.

PEREIRA, E. S.; PIMENTEL, P. G.; BONFIM, M. A. D.; CARNEIRO, M. S. S.; CÂNDIDO, M. J. D. Torta de girassol em rações de vacas em lactação: produção microbiana, produção, composição e perfil de ácidos graxos do leite. Acta Scientiarium Animal Science, Maringá, v. 33, n. 4, p. 387-394, 2011.

PEREIRA, E. S.; REGADAS FILHO, J. G. L.; FREITAS, E. R.; NEIVA, J. N. M.; CANDIDO, M. J. D. Valor energético de subprodutos da agroindústria brasileira. Archivos de Zootecnia, Córdoba, v. 58, n. 223, p. 455458, 2009.

RABELO, E.; REZENDE, R. L.; BERTICS, S. J.; GRUMMER, R. R. Effects of transition diets varying in dietary energy density on lactation performance and ruminal parameters of dairy cows. Journal of Dairy Science, Madison, v. 86, n. 3, p. 916-925, 2003.

RIIS, P. M. The pools of tissue constituents and products: proteins. In: RIIS, P. M. (Ed.). Dynamic biochemistry of animal production. New York: Elsevier, 1983. p. 75-108.

SANTOS, A. X.; OLIVEIRA, A. A.; MASSARO JUNIOR, F. L.; LANÇANOVA, J. A. C.; SILVA, L. D. F.; PECORARO, C.; LEME, M. C. J. Torta de girassol na dieta de vacas em lactação. In: REUNIÃO ANUAL DA SOCIEDADE BRASILEIRA DE ZOOTECNIA, 46., 2009, Maringá. Anais... Maringá: SBZ, 2009. CD-ROM.

SNIFFEN, C. J.; O'CONNOR, J. D.; VAN SOEST, P. J.; FOX, D. G.; RUSSELL, J. B. A net carbohydrate and protein system for evaluation cattle diets. II. Carbohydrate and protein availability. Journal of Animal Science, Madison, v. 70, n. 11, p. 3562-3577, 1992.

STATISTICAL ANALYSIS SYSTEM - SAS. SAS system for windows: version 9.0. SAS Institute, Cary, NC, 2005.

VALADARES FILHO, S. C.; VALADARES, R. D. F. Recentes avanços em proteína na nutrição de vacas leiteiras. In: SIMPÓSIO INTERNACIONAL NOVOS CONCEITOS EM NUTRIÇÃO, 2., 2001, Lavras. Anais... Lavras: SINLEITE, 2001. p. 229-247.

VAN SOEST, P. J.; ROBERTSON, J. B.; LEWIS, B. A. Methods for dietary fiber, neutral detergent fiber, and non starch polysaccharides in relation to animal nutrition. Journal of Dairy Science, Madison, v. 74, n. 10, p. 35833597, 1991. 
